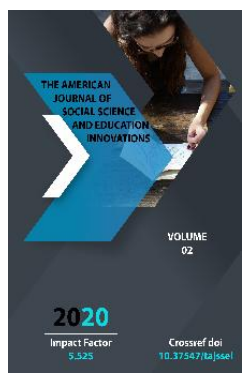

\title{
The Role Of Ceramics In Professional Training Of Young People In The Modern Education System
}

\section{Oripov Boburjon Badirjanovich}

Lecturer of the Department of Fine and Applied Art, Namangan State University, Uzbekistan

Journal Website:

http://usajournalshub.c

om/index,php/tajssei

Copyright: Original

content from this work

may be used under the

terms of the creative

commons attributes

4.0 licence.

\section{ABSTRACT}

This article discusses the history, features of the types of Uzbek applied art and illustrative materials that characterize them. It also gives an idea of the role and importance of applied art in the education system. In addition, the conditions created for the development of applied art in Uzbekistan and the expected results are reflected.

The modern education system has its own peculiarities of artistic and aesthetic education of youth through applied art, which, in turn, plays an important role in the education of youth as a person. Indeed, in the content of applied art, we have a long history, classic heritage, and national traditions. Therefore, its role is especially important in educational institutions. In this regard, the problems of artistic and aesthetic education and upbringing played an important role in the formation of a spiritually mature generation, taking into account universal and national values, the creative experience of our ancestors and centuries-old traditions.

\section{KEYWORDS}

Analysis, art, culture, teachers, masters of craft, applied art, modern education, traditions.

\section{INTRODUCTION}

After the independence of the Republic had been obtained, significant changes have taken place in the craft sector as in all other fields. A vivid example of this can be the Order "On 
measures of state support for the further development of folk arts and crafts" issued on 31st of March, 1997. According to the order, the state guarantees the exemption of artisans from paying the state tax, freedom of creativity, free sale of their products, participation in international exhibitions, participation in art organizations and creative work abroad.

The craft is an important form of the modern work sphere in the development of urban life. Crafting is a commercial process that takes place in a crowded place.

In this modern world and the development of the country, upbringing young generation with the sense of hard work, honesty and kindness is one of the important requirements of today. Especially in this regard, it is important to establish schools of crafts that were organized, developed and traditionally established in this area which plays a special role in the formation of qualities.

\section{MATERIALS AND METHODS}

It is well known that the values and traditions of the applied arts play a special role in the professional education of young people. As the master teaches his students the development and truthfulness of entrepreneurial and business skills using economic knowledge and concepts, he also transfers the secrets of people who have some educational qualities such as honest work, making money, persistent success, contributing to the development of society rather than just stopping their work.

Every person can learn craft as a hobby. It does not matter what kind of job people have in the world, crafting has masters and students. They are masters of handicrafts in the field of engraving, knitting, carpet weaving, wood engraving. Among them are gypsies, painters, swimmers, blacksmiths, bone carpenters, bricklayers, retailers, jewelers, wood carpenters and other artisans. In the past, handicrafts and natural sciences were taught individually to pupils who did not attend to schools in the following forms:

- Mastering paternity or raising children;

- In the form of parent -apprentice;

- As an apprentice of a master;

- In-store training, i.e. individual seminars in organized workshops.

Currently, during the time when national crafts are developing, masters teach their skills to their students of Master's Degree, based on our national traditions. But when a young master does a little good, he is immediately called a teacher. Really? Is the master worthy of the title "Master"? Who is Master? Who can we call a teacher? What is their role? How did the teachers keep discipline the past? It is difficult to find answers to such questions.

In ancient times, every craft was sacred and respected. Our ancestors developed their own customs, special rules, customs, and culture for teachers and students. Master-apprentice relationships have their own customs and national traditions and both the master and apprentice has their own responsibilities.

The personal and professional qualities of the craftsmen were as the following:

From the earliest times, craftsmen were accepted unique to their personal and professional qualities and were deeply respected. These personality traits as generosity, well-manner, compassion, openheartedness, good nature, patience, strictness, obedience, correct speech, purity 
and gentleness were important as an example of a teacher to his students.

Masters had a professional culture that includes:

- Training in a craft, not in order to obtain wealth, but to contribute to the development of society;

- Protection of the craft from unskilled income;

- Respect for the traditions of teachers;

- The sense of the nobleness;

- Receiving the blessing of the saints;

- Not to be indifferent to work;

- Hard and honest work;

- Being disciplined;

- Not getting depressed on a failure;

- Be a smart entrepreneur by profession;

- Being honest;

- Being open;

- Not gossiping.

Responsibilities of being a craftsman were:

- Avoiding dishonest contact with wealthy people;

- Not envying other professions and success of other people;

- Avoid stupidity, laziness, wasting, arrogance and deception.

The professional qualities of a teacher include his interest in his profession, passion for teaching young people, innovations, and leaving behind good, devoted students.

One of the best qualities of a teacher is the ability to having and teaching apprentices. Also, every master becomes a disciple. Artisans traditionally keep their craft from generation to generation. If a master did not leave any talented student behind, his life will be purposeless. No matter how good a master is, no matter how well he knows his craft, he cannot continue his work unless he shares his knowledge and skills to a trustworthy person. That's why Alisher Navoi wrote his following famous verses:

What would I do to keep my art?

Would I take it to the vault?

In ancient times, there was a common spirit and criteria for the relationship between artisans and buyers. They included: innocence, honesty, fairness, benevolence, selfindulgence, generosity, especially to the poor, and being honest when communicating with those who do not know the true value of the product, keeping vows, and avoiding the ones that cannot be fulfilled, and so on.

At the same time, there was a rule of behavior for apprentices:

- Having a good attitude to work, that is, love craft;

- Respecting and relying on their work;

- Giving up bad habits or behavior in front of the master;

- Carefully monitoring everything that are not necessary to do;

- Not eavesdropping;

- Avoiding all unnecessary actions;

- Not communicating with people who displeased the teacher.

The duties and responsibilities of the student to the teacher were developed by masters in the past. Students were to be obedient to the teacher, follow the traditions of the craft and instructions of their master, show patience, not to look at the teacher's face or right into his eyes, keep his reputation, not to be friends with the teacher's enemies, respect the master's family members, not to touch anything without master's permission, be respectful to other students and etc. 


\section{RESULTS AND DISCUSSIONS}

In the past, parents also honored the teacher who taught their children. The culture of communication between parents and teachers was also characteristic. They consisted of the following moral concepts:

Parent-teacher communication:

- Show kindness to the teacher;

- Correct understanding of the teacher's reproach;

- Acquire the necessary skills from the child, master the skills to help the teacher.

- Teacher-parent communication:

- To perform the duties of teaching the child skills;

- Fulfill a promise;

- Talking to parents about their child's abilities and behavior.

All of the above information is taken from the scientific article by S. Bulatov "Personal and professional qualifications of a teacher". In his large-scale fundamental research "Uzbek folk arts and crafts", 60 volumes, there is information on customs and traditions of Uzbek applied arts. His work analyzes the given information in detail from a scientific and theoretical point of view. This research work reflects the history, features of all types of Uzbek applied art, illustrative materials that characterize them. Nevertheless, the book does not provide analysis of pedagogical and methodological aspects of some popular crafts.

However, this paper is the main source for further research. The talented scientist $\mathrm{S}$. Bulatov and his students conduct research work on the problems of studying Uzbek crafts in the historical, ethnographic, philosophical, spiritual and educational aspects of applied art.
The value and traditions of applied arts are very important in the modern education system. Culture and art are undoubtedly important as an artistic event. The process of exploring the history of art, its place in the history of the Motherland and the nation; observing the present day, improving the content of education through its synthetic implementation of its results; and determining its future is continuous.

Based on the above, we can conclude that art is a spiritual phenomenon, since it is an artistic event and has a direct impact on improving education.

No society can exist without education and training of any kind. It is this philosophical definition that characterizes education, the social significance and importance of the pedagogical science that studies it. Thus, the social problems of every society include pedagogical problems associated with the study of the educational possibilities of culture and art. Its content and needs are determined by the social order at a certain stage in the development of society.

\section{CONCLUSION}

The modern education system has its own characteristics of artistic and aesthetic education of young people through applied arts, which, in turn, plays an important role in educating young people as individuals. Indeed, in the content of applied art we have a long history, classical heritage, national traditions. Therefore, its role is especially important in educational institutions. In this regard, the problems of artistic and aesthetic education and upbringing also played an important role in the formation of a spiritually mature generation, taking into account 
universal and national values, the creative experience of our ancestors and centuries-old traditions. The high human qualities of young people, their interest in the spiritual heritage of our ancestors and their innate abilities can be effectively formed when they are young. In this respect, folk art has its merits. The customs of all nations and nationalities in the world have spiritual and material values. The spiritual world of each nation is reflected in the norms of morality, its traditions and influences the moral formation of the individual.

\section{REFERENCES}

1. Islam Karimov. Uzbekistan on the threshold of independence. 2011.

2. G. Darvez. Album. Yadova L., Yadanka I., Mitlyansky D., Contemporary ceramics of folk craftsmen of Central Asia. // "Soviet Goddess", M., 1974.

3. A.A.Khakimov. Soviet art of Uzbekistan. 1987 No.7.

4. M.Ahmedov. Listening to a pottery story. Art and Literature of Uzbekistan. 1992. No.47

5. M.Matkarimov. Ceramics in Gurumsarai// The Regional Newspaper of Pop, 1993 No.47

6. M.Matkarimov.The owner of fine art// The Regional Newspaper of Pop, 1993 No.22

7. Sarimsakova, D. (2019). Communicative competence as a result of EF teaching and learning ISJ Theoretical \& Applied Science, 12 (80), 166-169 https://dx. doi. org/10.15863. In TAS (Vol. 80). 